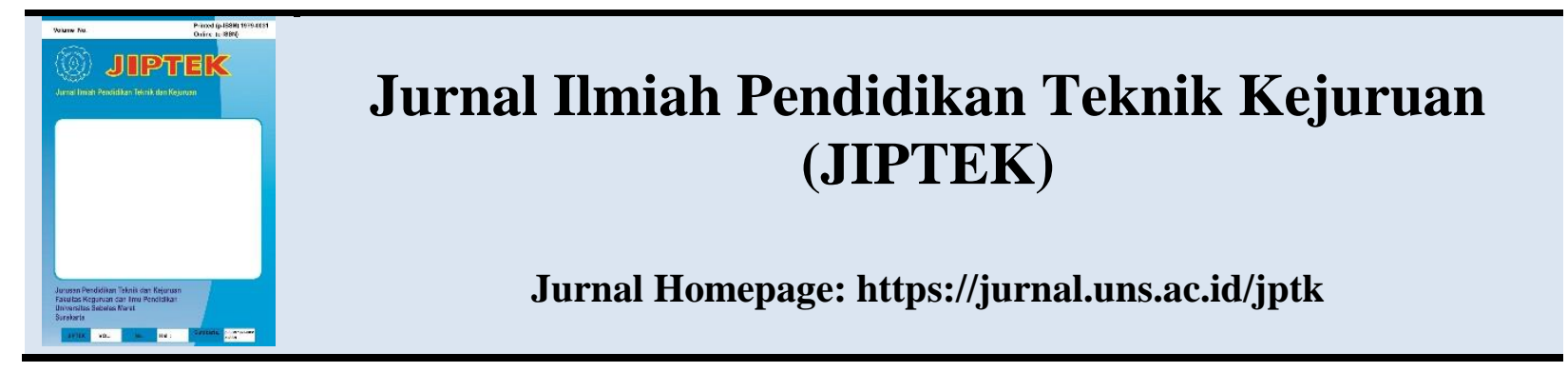

\title{
PENGARUH PERSEPSI SISWA MENGENAI KOMPETENSI GURU TERHADAP PRESTASI BELAJAR SISWA PADA MATA PELAJARAN SISTEM KOMPUTER DI SMK NEGERI 1 BANYUDONO
}

\author{
${ }^{1}$ Nada Hanifah, ${ }^{1}$ Agus Efendi, dan ${ }^{\mathbf{1}}$ A.G. Tamrin \\ ${ }^{1}$ Program Studi Pendidikan Teknik Informatika dan Komputer Universitas Sebelas Maret \\ Email: nadahanifah22@gmail.com
}

\begin{abstract}
ABSTRAK
Penelitian ini bertujuan untuk mengetahui (1) pengaruh persepsi siswa mengenai kompetensi pedagogik guru terhadap prestasi belajar siswa pada mata pelajaran sistem komputer; (2) pengaruh persepsi siswa mengenai kompetensi kepribadian guru terhadap prestasi belajar siswa pada mata pelajaran sistem komputer; (3) pengaruh persepsi siswa mengenai kompetensi sosial guru terhadap prestasi belajar siswa pada mata pelajaran sistem komputer; (4) pengaruh persepsi siswa mengenai kompetensi profesional guru terhadap prestasi belajar siswa pada mata pelajaran sistem komputer; (5) pengaruh persepsi siswa mengenai kompetensi pedagogik guru, kompetensi kepribadian guru, kompetensi sosial guru, dan kompetensi profesional guru secara bersama - sama terhadap prestasi belajar siswa pada mata pelajaran sistem komputer. Populasi dalam penelitian ini adalah siswa kelas X dan XI jurusan TKJ di SMK Negeri 1 Banyudono. Penelitian ini merupakan penelitian kuantitatif dengan metode survei. Pengumpulan data menggunakan metode angket dan dokumentasi. Analisis data menggunakan regresi ganda. Hasil penelitian ini adalah sebagai berikut ini. Pertama, tidak terdapat pengaruh yang positif dan signifikan persepsi siswa mengenai kompetensi pedagogik guru terhadap prestasi belajar siswa pada mata pelajaran sistem komputer di SMK Negeri 1 Banyudono. Kedua, tidak terdapat pengaruh yang positif dan signifikan persepsi siswa mengenai kompetensi kepribadian guru terhadap prestasi belajar siswa pada mata pelajaran sistem komputer di SMK Negeri 1 Banyudono. Ketiga, tidak terdapat pengaruh yang positif dan signifikan persepsi siswa mengenai kompetensi sosial guru terhadap prestasi belajar siswa pada mata pelajaran sistem komputer di SMK Negeri 1 Banyudono. Keempat, terdapat pengaruh yang positif dan signifikan persepsi siswa mengenai kompetensi profesional guru terhadap prestasi belajar siswa pada mata pelajaran sistem komputer di SMK Negeri 1 Banyudono. Kelima, terdapat pengaruh yang positif dan signifikan persepsi siswa mengenai kompetensi pedagogik guru, kompetensi kepribadian guru, kompetensi sosial guru, dan kompetensi profesional guru secara bersama - sama terhadap prestasi belajar siswa pada mata pelajaran sistem komputer di SMK Negeri 1 Banyudono.
\end{abstract}

Kata Kunci: persepsi siswa, kompetensi guru, prestasi belajar 


\begin{abstract}
The purpose of this study was to determine: (1) the influence of students perception about paedagogic competence of computer system teacher towards students' achievement;

(2) the influence of students perception about personal competence of computer system teacher towards students' achievement; (3) the influence of students perception about social competence of computer system teacher towards students' achievement; (4) the influence of students perception about professional competence of computer system teacher towards students' achievement; and (5) the influence of students perception about paedagogic, personal, professional, and social competence of computer system teacher towards students' achievement. The population in this study were students of computer and network engineering course at State Vocational High School 1 Banyudono. The research was using quantitative approach with survey methods. Data were collected by questionnaire methods and documentation. Those data were analyzed with multiple regression analysis to answer the 1, 2, 3, 4 , and 5 hypothesis. The result of this research were: First, there is no positive and significant influence students perception about paedagogic competence of computer system teacher towards students' achievement at State Vocational High School 1 Banyudono. Second, there is no positive and significant influence students perception about personal competence of computer system teacher towards students' achievement at State Vocational High School 1 Banyudono. Third, there is no positive and significant influence students perception about social competence of computer system teacher towards students' achievement at State Vocational High School 1 Banyudono. Fourth, there is positive and significant influence students perception about professional competence of computer system teacher towards students' achievement at State Vocational High School 1 Banyudono. Fifth, there is positive and significant influence students perception about paedagogic, personal, professional, and social competence of computer system teacher towards students' achievement at State Vocational High School 1 Banyudono which was shown by the score of correlation of determination $\left(R^{2}\right)$ was 49,3 and $F_{\text {hitung }}$ was higher than $F_{\text {tabel }}$ which was 22,816 >2,70 at the significance level 5\%.
\end{abstract}

\title{
Keywords: students' perception, teacher's competency, student's achievement
}




\section{PENDAHULUAN}

\section{Latar Belakang Masalah}

Undang - undang Republik Indonesia nomor 14 tahun 2005 tentang Guru dan Dosen (2005:4) pasal 2 ayat 1 menyebutkan Guru mempunyai kedudukan sebagai tenaga profesional pada jenjang pendidikan dasar, pendidikan menengah, dan pendidikan anak usia dini pada jalur pendidikan formal yang diangkat sesuai dengan peraturan perundang- undangan. Salah satu peran guru sebagai agen pembelajaran berfungsi untuk meningkatkan mutu pendidikan nasional. Undang - undang ini dijadikan acuan oleh guru untuk terus meningkatkan kemampuannya sesuai perkembangan zaman dalam rangka peningkatan mutu pendidikan dari tahun ke tahun.

Guru harus mempunyai kompetensi yang menunjang untuk mengatasi tuntutan zaman. Kriteria - kriteria yang ada semakin meningkat karena guru harus mampu mencetak siswa yang mampu bersaing secara global, bukan hanya sekadar tingkat sekolah ataupun nasional. Pendapat dari Elaine B. Johnson (Naim, 2009: 15) menyatakan bahwa guru yang bermutu memungkinkan siswanya untuk tidak hanya dapat mencapai standar nilai akademik secara nasional, tetapi juga mendapatkan pengetahuan dan keahlian yang penting untuk belajar selama hidup mereka. Pencapaian standar nasional tidaklah penting jika hasil tersebut hanya digunakan sebagai syarat kelulusan, tanpa adanya pengetahuan dan juga keahlian yang penting untuk belajar selama hidup mereka. Guru sebagai seorang pendidik hendaknya memiliki kompetensi pendukung agar peserta didik memiliki bekal yang cukup untuk menghadapi globalisasi.

Kompetensi guru adalah suatu kewajiban bagi semua guru. Guru yang memiliki kemampuan atau dengan kata lain guru yang profesional akan dapat menyelenggarakan proses pembelajaran dan penilaian objektif bagi siswa, sehingga dapat mendorong tumbuhnya kreatifitas belajar pada diri siswa. Jadi disini, pengaruh kompetensi guru adalah sejauh mana guru itu dapat mencapai keberhasilan dalam proses belajar mengajar karena akan menimbulkan pengaruh siswa terkait dengan penglihatanya terhadap seorang guru. Faktor tersebut kemudian akan dirangsang dan menantang siswa untuk terlibat penuh dalam proses belajar mengajar. Sehingga disini pencapaian prestasi belajar tergantung pada kompetensi yang dimiliki oleh seorang guru dalam pembelajaran. Jika guru mempunyai kompetensi yang baik maka, prestasi belajar siswa dapat berubah menjadi lebih baik lagi.

Guru mata pelajaran sistem komputer di SMK Negeri 1 Banyudono adalah guru baru yang belum memiliki sertifikat pendidik, sehingga kinerjanya belum dinilai menggunakan penilaian kinerja guru yang diatur oleh undang - undang. Selain itu, guru tersebut merupakan guru fresh graduate yang mulai mengajar dari tahun ajaran 2015/2016 sehingga bisa disimpulkan bahwa guru tersebut pengalaman mengajarnya kurang dari satu tahun.

Persepsi siswa menjadi penting untuk diketahui, sesuai dengan penelitian dari Pangestuti (2012) dalam abstrak penelitiannya yang menyatakan bahwa kompetensi guru memberikan kontribusi terhadap prestasi belajar sebesar 66,4\%. Selain itu, Yunita (2013) menyatakan bahwa kompetensi profesional guru mempengaruhi hasil belajar siswa sebesar $25,9 \%$. Berdasarkan beberapa penelitian yang terkait, persepsi siswa terhadap kompetensi guru memiliki kontribusi terhadap prestasi belajar siswa.

\section{Tujuan Penelitian}

(1) Untuk mengetahui pengaruh persepsi siswa mengenai kompetensi pedagogik guru terhadap prestasi belajar siswa pada mata pelajaran sistem komputer di SMK Negeri 1 Banyudono. (2) Untuk mengetahui pengaruh persepsi siswa mengenai kompetensi kepribadian guru terhadap prestasi belajar siswa pada mata pelajaran sistem komputer di SMK Negeri 1 Banyudono. (3) Untuk mengetahui pengaruh persepsi mengenai kompetensi sosial guru terhadap prestasi belajar siswa pada mata pelajaran sistem komputer di SMK Negeri 1 Banyudono. (4) Untuk mengetahui pengaruh persepsi siswa mengenai kompetensi profesional guru terhadap prestasi belajar siswa pada mata pelajaran sistem komputer di SMK Negeri 1 Banyudono. (5) Untuk mengetahui pengaruh persepsi siswa mengenai kompetensi guru pedagogik guru, kompetensi kepribadian guru, kompetensi sosial guru, kompetensi profesional guru secara bersama - sama terhadap prestasi belajar siswa pada mata pelajaran sistem komputer di SMK Negeri 1 Banyudono. 


\section{Kajian Pustaka}

Undang - Undang Republik Indonesia profesional adalah kemampuan penguasaan materi Nomor 14 Tahun 2005 tentang Guru dan Dosen pembelajaran secara luas dan mendalam yang menjelaskan bahwa kompetensi adalah memungkinkan membimbing peserta didik seperangkat pengetahuan, keterampilan, dan memenuhi standar kompetensi yang ditetapkan perilaku yang harus dimiliki, dihayati, dan dalam Standar Nasional Pendidikan. Ratminingsih dikuasai oleh guru atau dosen dalam (2015: 36) menyebutkan bahwa kompetensi melaksanakan tugas keprofesionalan. Mulyasa profesional menyangkut kemampuan dalam bidang (2007: 25) yang mengutip simpulan Broke and studi yang ditekuni oleh masing - masing guru.

Stone mengemukakan bahwa kompetensi guru sebagai ... descriptive of qualitaive nature of teacher behavior apears to be entirely meaningful. ... kompetensi guru merupakan gambaran kualitatif tentang hakikat perilaku guru yang penuh arti. Dari beberapa penjelasan tentang kompetensi guru dapat disimpulkan bahwa kompetensi guru adalah kemampuan guru pengetahuan, keterampilan, dan perilaku) yang harus dimiliki dalam melaksanakan tugas sebagai guru serta guna mencapai tujuan sebagai guru.

Kompetensi merupakan standar utama bagi seorang guru dan bukan merupakan sebuah tujuan melainkan sebuah proses yang terus berkembang. Kompetensi guru yang diatur dalam Peraturan Menteri Pendidikan Nasional Nomor 16 Tahun 2007 tentang Standar Kualifikasi Akademik dan Kompetensi Guru mencakup empat (4) aspek kompetensi, yaitu kompetensi pedagogik, kompetensi kepribadian, kompetensi profesional, dan kompetensi sosial.

\section{Kompetensi Pedagogik}

Dalam Standar Nasional Pendidikan, penjelasan Pasal 28 ayat (3) butir a dikemukakan bahwa kompetensi pedagogik adalah kemampuan mengelola pembelajaran peserta didik yang meliputi pemahaman terhadap peserta didik, perancangan dan pelaksanaan pembelajaran, evaluasi hasil belajar, dan pengembangan peserta didik untuk mengaktualisasikan berbagai potensi yang dimilikinya.

\section{Kompetensi Kepribadian}

Dalam Standar Nasional Pendidikan, penjelasan Pasal 28 ayat (3) butir b dijelaskan bahwa kompetensi kepribadian adalah kemampuan kepribadian yang mantap, stabil, menyatakan bahwa kompetensi guru memberikan dewasa, arif dan berwibawa, menjadi teladan bagi kontribusi terhadap prestasi belajar sebesar $66,4 \%$. peserta didik, dan berakhlak mulia.Kompetensi Selain itu, Yunita (2013) menyatakan bahwa Profesional Dalam Standar Nasional Pendidikan, kompetensi profesional guru mempengaruhi hasil penjelasan Pasal 28 ayat (3) butir c dijelaskan belajar siswa sebesar 25,9\%. Berdasarkan beberapa bahwa yang dimaksud dengan kompetensi

penelitian yang terkait, persepsi siswa terhadap kompetensi guru memiliki kontribusi terhadap hasil 
belajar siswa.

\section{Prestasi Belajar}

Prestasi menurut Feralys (2015 : 52) adalah kemampuan yang dicapai seseorang dalam melakukan kegiatan tertentu. Dalam jurnalnya, Feralys (2015: 52) juga menguraikan bahwa belajar adalah suatu kegiatan yang dilakukan oleh seseorang dălam rangka memperoleh ilmu pengetahuan, keterampilan dan sikapnya yang baik serta bermanfaat dalam kehidupan. Prestasi belajar menurut Isnanto (2005 : 15) adalah hasil yang telah dicapai setelah siswa mendapat pengajaran dalam waktu tertentu. Hasil pengajaran dapat dikatakan berhasil apabila pengajaran itu mencapai tujuan yang ingin diraih. Jadi dapat disimpulkan bahwa prestasi belajar siswa merupakan hasil yang dicapai siswa dengan kurun waktu tertentu setelah melalui proses belajar mengajar di kelas. Prestasi belajar ini ditunjukkan dengan adanya nilai rapot siswa.

\section{METODE PENELITIAN}

Penelitian ini menggunakan pendekatan kuantitatif dengan metode survey. Metode penelitian survey bertujuan untuk mengumpulkan data mengenai pengaruh persepsi siswa mengenai kompetensi pedagogik guru, persepsi siswa mengenai kompetensi kepribadian guru, persepsi siswa mengenai kompetensi profesional guru, persepsi siswa mengenai kompetensi sosial guru terhadap variabel terikat yaitu prestasi belajar siswa.

Penelitian ini dilaksanakan di Sekolah Menengah Kejuruan Negeri 1 Banyudono yang beralamatkan di Jalan Kuwiran 3, RT 12 RW 04, Kecamatan Banyudono, Kabupaten Boyolali, telepon (0271) - 781834, kode pos 57373, Jawa Tengah.

Populasi dalam penelitian ini adalah siswa jurusan TKJ SMK Negeri 1 Banyudono. Sampel penelitian dipilih menggunakan teknik simple random sampling. digunakan:

Berikut perhitungan sampel yang akan

Tabel 3.1. Jumlah Siswa

\begin{tabular}{lll}
\hline Kelas & & Jumlah Siswa \\
\cline { 1 - 1 } X TKJ 1 & & 33 \\
X TKJ 2 & & 30 \\
XI TKJ 1 & & 35 \\
XI TKJ 2 & $\underline{34}$ \\
\cline { 1 - 1 } TOTAL & $\underline{132}$ \\
\hline
\end{tabular}

Penentuan jumlah sampel menggunakan rumus yang dikemukakan oleh Slovin yaitu:

$$
\begin{aligned}
& n=\quad \begin{array}{l}
n \\
n=\quad N \alpha^{2} \\
n=99,2
\end{array} \\
& \quad 1+132(0,05.0,05)
\end{aligned}
$$

Sampel dalam penelitian ini berjumlah 99 siswa. Teknik pengumpulan data adalah menggunakan dokumentasi dan kuesioner. Dokumentasi digunakan untuk mendapatkan nilai rapot siswa dan kuesioner digunakan untuk memetakan persepsi siswa mengenai kompetensi guru.

Validitas yang akan digunakan oleh peneliti adalah validitas konstrak (construct validity), dimana pengujiannya dilakukan oleh beberapa ahli. Selanjutnya dilakukan penghitungan validitas tiap butir instrument menggunakan rumus korelasi product moment Pearson.

Setelah dilakukan uji coba pada 32 responden, diperoleh hasil uji validitas instrumen yaitu semua butir dinyatakan valid.

Pengujian reliabilitas instrumen yang digunakan peneliti adalah dengan Rumus Alpha Cronbach. Hasil perhitungan menunjukkan bahwa kuesioner persepsi siswa mengenai kompetensi pedagogik guru mempunyai tingkat reliabilitas yang sangat tinggi yaitu 0,949, kuesioner persepsi siswa mengenai kompetensi kepribadian guru mempunyai tingkat reliabilitas yang sangat tinggi yaitu 0,950 , kuesioner persepsi siswa mengenai kompetensi profesional guru mempunyai tingkat reliabilitas yang sangat tinggi yaitu 0,927 , dan kuesioner persepsi siswa mengenai kompetensi sosial guru mempunyai tingkat reliabilitas yang sangat tinggi yaitu 0,938 .

Teknik analisis data dalam penelitian ini terdiri dari beberapa langkah yaitu: (1) deskripsi data: (a) mean, median, modus, (b) tabel distribusi frekuensi, (c) standar deviasi, (d) histogram, (e) tabel kecenderungan variabel (2) uji prasyarat: (a) uji normalitas (b) uji linieritas (c) uji multikolinieritas (d) uji heterokesdastisitas dan (3) pengujian hipotesis menggunakan analisis regresi berganda. 


\section{HASIL DAN PEMBAHASAN}

\section{Hasil Penelitian}

Deskripsi hasil penelitian adalah sebagai berikut:

Persepsi Siswa mengenai Kompetensi Pedagogik Guru

Mean, median, modus, dan standar deviasi dapat dilihat pada tabel 4.1

Tabel 4.1. Statistik Deskriptif Persepsi Siswa mengenai Kompetensi Pedagogik Guru

\begin{tabular}{ll}
\hline \multicolumn{2}{c}{ Statistik Deskriptif } \\
\hline Mean & 63,76 \\
Median & 64,00 \\
Mode & 60 \\
Std. & \multicolumn{2}{l}{4,916} \\
Deviation &
\end{tabular}

Tabel distribusi frekuensi variabel persepsi siswa mengenai kompetensi pedagogik guru dapat dilihat pada tabel 4.2.

Tabel 4.2. Distribusi Frekuensi Variabel Persepsi Siswa mengenai Kompetensi Pedagogik Guru $\left(\mathrm{X}_{1}\right)$

\begin{tabular}{llll}
\hline No & Interval & Frekuensi & $\begin{array}{l}\text { Persentase } \\
(\%)\end{array}$ \\
\cline { 3 - 4 } 1 & $50-52$ & 1 & $1,01 \%$ \\
2 & $53-55$ & 2 & $2.02 \%$ \\
3 & $56-58$ & 11 & $11,11 \%$ \\
4 & $59-61$ & 24 & $24,24 \%$ \\
5 & $62-64$ & 18 & $18,18 \%$ \\
6 & $65-67$ & 17 & $17,17 \%$ \\
7 & $68-70$ & 17 & $17,17 \%$ \\
8 & $\frac{71-73}{\text { Total }}$ & $\frac{9}{99}$ & $\frac{99 \%}{100 \%}$ \\
\hline
\end{tabular}

Diagram dari hasil perhitungan distribusi frekuensi dapat dilihat pada gambar 4.1 berikut ini:

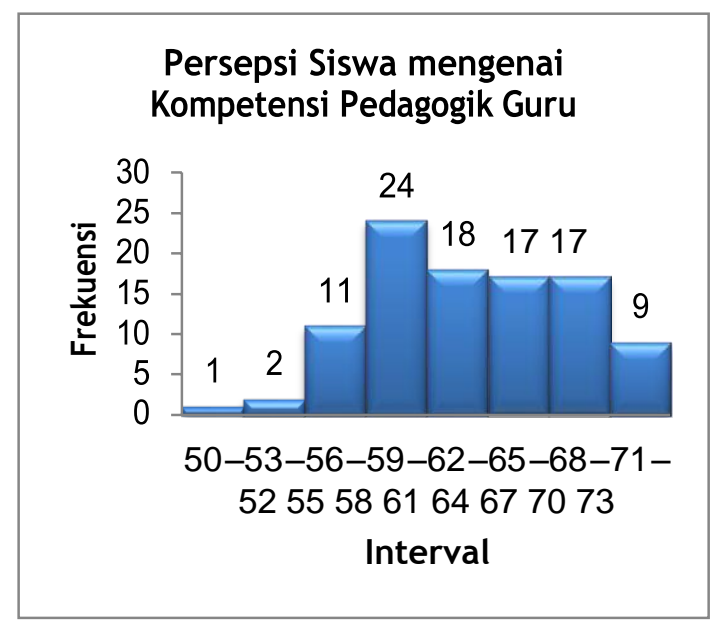

Gambar 4.1. Diagram Batang Persepsi Siswa mengenai Kompetensi Pedagogik Guru

Kecenderungan persepsi siswa mengenai kompetensi pedagogik guru dapat dilihat pada tabel 4.3.

Tabel 4.3. Distribusi Kecenderungan Persepsi Siswa mengenai Kompetensi Pedagogik Guru

\begin{tabular}{|c|c|c|c|c|}
\hline$\overline{\mathrm{Nc}}$ & Skor & Jumlah & $\begin{array}{l}\text { Persentase } \\
(\%)\end{array}$ & Kategori \\
\hline 1 & $<57,4$ & 7 & $7,07 \%$ & Rendah \\
\hline 2 & $\begin{array}{c}57,4- \\
64,6\end{array}$ & 49 & $49,49 \%$ & Sedang \\
\hline 3 & $\geq 64,6$ & $\underline{43}$ & $43,43 \%$ & Tinggi \\
\hline & Total & 99 & $100.00 \%$ & \\
\hline
\end{tabular}

Sumber : Data Primer yang diolah (2016)

\section{Persepsi Siswa mengenai Kompetensi Kepribadian Guru}

Mean, median, modus, dan standar deviasi dapat dilihat pada tabel 4.4.

Tabel 4.4. Statistik Deskriptif Persepsi Siswa mengenai Kompetensi Kepribadian Guru

\begin{tabular}{ll}
\hline \multicolumn{2}{c}{ Statistik Deskriptif } \\
\hline Mean & 63.47 \\
Median & 63.00 \\
Mode & 63 \\
Std. Deviation & 4.984 \\
\hline
\end{tabular}


Tabel distribusi frekuensi variabel persepsi siswa mengenai kompetensi pedagogik guru dapat dilihat pada tabel 4.5 .

Tabel 4.5. Distribusi Frekuensi Variabel Persepsi Siswa mengenai Kompetensi Kepribadian Guru $\left(\mathrm{X}_{2}\right)$

\begin{tabular}{llll}
\hline No & Interval & Frekuensi & $\begin{array}{l}\text { Persentase } \\
(\%)\end{array}$ \\
1 & $43-46$ & 1 & $1.01 \%$ \\
2 & $47-50$ & 2 & $2.02 \%$ \\
3 & $51-54$ & & $0.00 \%$ \\
4 & $55-58$ & 4 & $4.04 \%$ \\
5 & $59-62$ & 33 & $33.33 \%$ \\
6 & $63-66$ & 35 & $35.35 \%$ \\
7 & $67-70$ & 13 & $13.13 \%$ \\
8 & T1-74 & 10 & $10.10 \%$ \\
\hline
\end{tabular}

Sumber : Data Primer yang diolah (2016) Diagram dari hasil perhitungan distribusi

frekuensi dapat dilihat pada gambar 4.2 berikut ini:

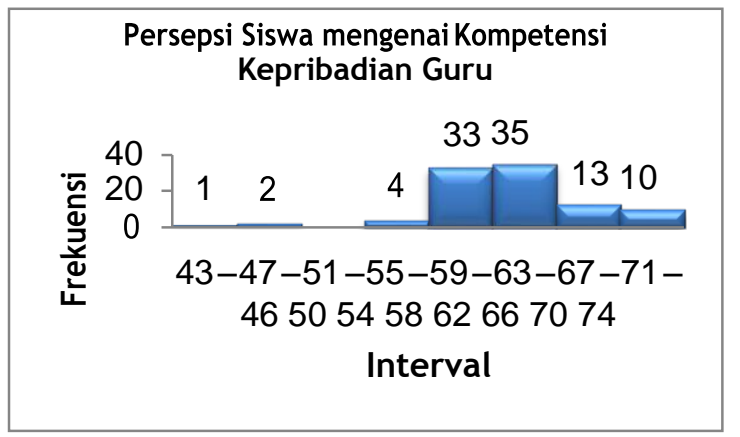

Gambar 4.2. Diagram Batang Persepsi Siswa mengenai Kompetensi Kepribadian Guru

Kecenderungan persepsi siswa mengenai kompetensi kepribadian guru dapat dilihat pada tabel 4.6.

Tabel 4.6. Distribusi Kecenderungan Persepsi Siswa mengenai Kompetensi

Kepribadian Guru

\begin{tabular}{lllll}
\hline No & Skor & $\begin{array}{l}\text { Jum } \\
\text { lah }\end{array}$ & $\begin{array}{l}\text { Persent } \\
\text { ase }(\%)\end{array}$ & Kategori \\
\hline 1 & $<55$ & 3 & $3,03 \%$ & Rendah
\end{tabular}

$$
\begin{aligned}
& \begin{array}{lllll}
2 & 55-64 & 59 & 59,60 \% & \text { Sedang }
\end{array} \\
& \underline{3} \frac{>64}{\text { Total }} \frac{37}{99} \frac{37,37 \%}{100.00} \text { Tinggi } \\
& \%
\end{aligned}
$$

Sumber : Data Primer yang diolah (2016)

\section{Persepsi Siswa mengenai Kompetensi Sosial Guru}

Mean, median, modus, dan standar deviasi dapat dilihat pada tabel 4.7.

Tabel 4.7. Statistik Deskriptif Persepsi Siswa mengenai Kompetensi Sosial Guru

\begin{tabular}{ll}
\hline \multicolumn{2}{c}{ Statistik Deskriptif } \\
\hline Mean & 37.71 \\
Median & 37.00 \\
Mode & 37 \\
Std. Deviation & 3.572 \\
\hline
\end{tabular}

Tabel distribusi frekuensi variabel persepsi siswa mengenai kompetensi sosial guru dapat dilihat pada tabel 4.8 .

Tabel 4.8. Distribusi Frekuensi Variabel Persepsi Siswa mengenai Kompetensi Sosial Guru $\left(\mathrm{X}_{3}\right)$

\begin{tabular}{llll}
\hline No & Interval & Frekuensi & $\begin{array}{l}\text { Persentase } \\
(\%)\end{array}$ \\
1 & $29-30$ & 1 & $1.01 \%$ \\
2 & $31-32$ & 6 & $6.06 \%$ \\
3 & $33-34$ & 11 & $11.11 \%$ \\
4 & $35-36$ & 19 & $19.19 \%$ \\
5 & $37-38$ & 27 & $27.27 \%$ \\
6 & $39-40$ & 12 & $12.12 \%$ \\
7 & $41-42$ & 10 & $10.10 \%$ \\
8 & $43-45$ & 13 & $13.13 \%$ \\
\hline & \multicolumn{1}{l}{ Total } & 99 & $100.00 \%$ \\
\cline { 1 - 2 } & &
\end{tabular}

Sumber : Data Primer yang diolah (2016)

Diagram dari hasil perhitungan distribusi frekuensi dapat dilihat pada gambar 4.3

berikut ini: 


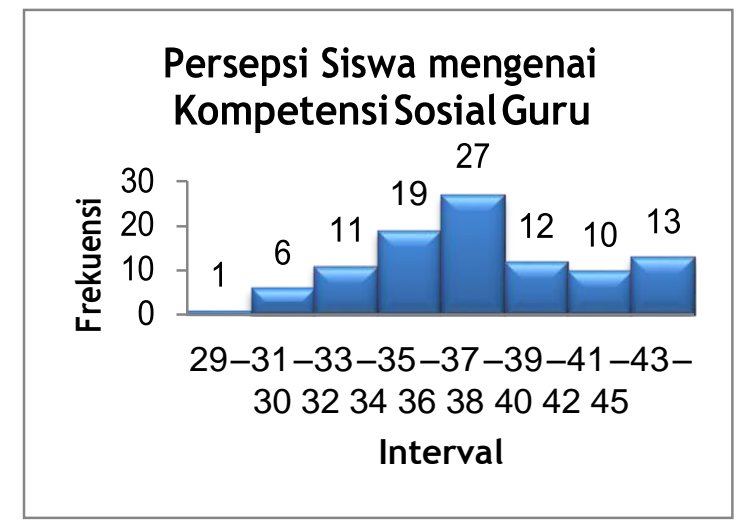

Gambar 4.3. Diagram Batang Persepsi Siswa mengenai Kompetensi Sosial Guru

Kecenderungan persepsi siswa mengenai kompetensi sosial guru dapat dilihat pada tabel 4.9.

Tabel 4.9. Distribusi Kecenderungan Persepsi Siswa mengenai Kompetensi Sosial Guru

\begin{tabular}{|c|c|c|c|c|}
\hline No & Skor & $\begin{array}{l}\text { Jum } \\
\text { lah }\end{array}$ & $\begin{array}{l}\text { Persenta } \\
\text { se }(\%)\end{array}$ & Kategori \\
\hline 1 & $<34,4$ & 5 & $5.05 \%$ & Rendah \\
\hline 2 & $\begin{array}{c}34,4- \\
39,6\end{array}$ & 67 & $67.68 \%$ & Sedang \\
\hline 3 & $\geq 39,6$ & 27 & $27.27 \%$ & Tinggi \\
\hline & Total & 99 & $100.00 \%$ & \\
\hline
\end{tabular}

Persepsi Siswa mengenai Kompetensi Profesional Guru

Mean, median, modus, dan standar deviasi dapat dilihat pada tabel 4.10.

Tabel 4.10. Statistik Deskriptif Persepsi Siswa mengenai Kompetensi Profesional Guru

\begin{tabular}{ll}
\hline \multicolumn{2}{c}{ Statistik Deskriptif } \\
\hline Mean & 45.8990 \\
Median & 45.0000 \\
Mode & 43.00 \\
Std. Deviation & 3.59562 \\
\hline
\end{tabular}

Tabel distribusi frekuensi variabel persepsi siswa mengenai kompetensi profesional guru dapat dilihat pada tabel 4.11

Tabel 4.11. Distribusi Frekuensi Variabel Persepsi Siswa mengenai Kompetensi Profesional Guru $\left(\mathrm{X}_{4}\right)$

\begin{tabular}{|c|c|c|c|}
\hline No & Interval & $\begin{array}{l}\begin{array}{l}\text { Freku } \\
\text { ensi }\end{array} \\
\end{array}$ & $\begin{array}{l}\text { Persentase } \\
(\%)\end{array}$ \\
\hline 1 & $39-40$ & 5 & $5.05 \%$ \\
\hline 2 & $41-42$ & 14 & $14.14 \%$ \\
\hline 3 & $43-44$ & 23 & $23.23 \%$ \\
\hline 4 & $45-46$ & 17 & $17.17 \%$ \\
\hline 5 & $47-48$ & 12 & $12.12 \%$ \\
\hline 6 & $49-50$ & 15 & $15.15 \%$ \\
\hline 7 & $51-52$ & 11 & $11.11 \%$ \\
\hline \multirow[t]{2}{*}{8} & $\underline{53-54}$ & $\underline{2}$ & $2.02 \%$ \\
\hline & Total & 99 & $100.00 \%$ \\
\hline
\end{tabular}

Diagram dari hasil perhitungan distribusi frekuensi dapat dilihat pada gambar 4.4 berikut ini:

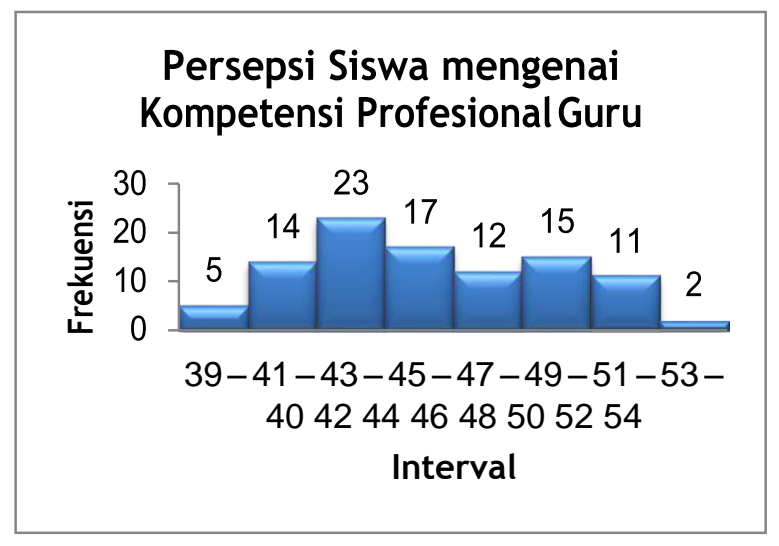

Gambar 4.4. Diagram Batang Persepsi Siswa mengenai Kompetensi Profesional Guru

Kecenderungan persepsi siswa mengenai kompetensi sosial guru dapat dilihat pada tabel 4.9. 
Tabel 4.12. Distribusi Kecenderungan Persepsi Siswa mengenai Kompetensi Profesional Guru

\begin{tabular}{|c|c|c|c|c|}
\hline No & Skor & $\begin{array}{l}\text { Jum } \\
\text { lah }\end{array}$ & $\begin{array}{l}\text { Persentase } \\
(\%)\end{array}$ & Kategori \\
\hline 1 & $<44,3$ & 31 & $31,31 \%$ & Rendah \\
\hline 2 & $\begin{array}{c}44,3- \\
48,7\end{array}$ & 40 & $40,40 \%$ & Sedang \\
\hline 3 & $>48,7$ & 28 & $28,28 \%$ & Tinggi \\
\hline
\end{tabular}

Sumber : Data Primer yang diolah (2016)

\section{Hasil Uji Hipotesis}

\section{Uji Hipotesis Pertama}

Dari hasil perhitungan regresi antara $\mathrm{X}_{1-}$ $\mathrm{Y}$ dapat diperoleh persamaan regresi sebagai berikut :

$$
\mathrm{UTS}=1,405+0,006 \mathrm{SP}
$$

Berdasarkan hasil perhitungan $\mathrm{X}_{1}-\mathrm{Y}$ dapat diketahui hasil perhitungan nilai $\mathrm{t}$ hitung sebesar 1,784 sedangkan $t$ tabel untuk $\alpha / 2=0,025$ dan derajat kebebasan 94 diperoleh 1,9. Dengan demikian $t$ hitung $<\mathrm{t}$ tabel, yaitu $1,784<1,9$, berarti persepsi siswa mengenai kompetensi pedagogik guru tidak mempunyai pengaruh signifikan terhadap prestasi belajar siswa. Begitu pula apabila dilihat dari nilai sig., nilai sig. variabel persepsi siswa mengenai kompetensi pedagogik guru sebesar 0,078>0,05, berarti variabel persepsi siswa mengenai kompetensi pedagogik guru tidak memiliki pengaruh signifikan terhadap prestasi belajar siswa. Dengan demikian, hipotesis yang menyatakan bahwa "Terdapat pengaruh positif dan signifikan persepsi siswa mengenai kompetensi pedagogik guru terhadap prestasi belajar siswa pada mata pelajaran sistem komputer di SMK Negeri 1 Banyudono" ditolak.

\section{Uji Hipotesis Kedua}

Dari hasil perhitungan regresi antara $\mathrm{X}_{2^{-}}$ $\mathrm{Y}$ dapat diperoleh persamaan regresi ebagai berikut :

$\mathrm{UTS}=1,405+0,006 \mathrm{SP}$

Berdasarkan hasil perhitungan $\mathrm{X}_{2}-\mathrm{Y}$ dapat diketahui hasil perhitungan nilai t hitung sebesar 1,669 sedangkan $t$ tabel untuk $\alpha / 2=0,025$ dan derajat kebebasan 94 diperoleh 1,9. Dengan demikian $\mathrm{t}$ hitung $<\mathrm{t}$ tabel, yaitu $1,669<1,9$, berarti persepsi siswa mengenai kompetensi kepribadian guru tidak mempunyai pengaruh signifikan terhadap prestasi belajar siswa. Begitu pula apabila dilihat dari nilai sig., nilai sig. variabel persepsi siswa mengenai kompetensi kepribadian guru sebesar $0,098<0,05$, berarti variabel persepsi siswa mengenai kompetensi kepribadian guru tidak memiliki pengaruh signifikan terhadap prestasi belajar siswa. Dengan demikian, hipotesis yang menyatakan bahwa "Terdapat pengaruh positif dan signifikan persepsi siswa mengenai kompetensi pedagogik guru terhadap prestasi belajar siswa pada mata pelajaran sistem komputer di SMK Negeri 1 Banyudono" ditolak.

\section{Uji Hipotesis Ketiga}

Dari hasil perhitungan regresi antara $\mathrm{X}_{3^{-}}$ $\mathrm{Y}$ dapat diperoleh persamaan regresi sebagai berikut :

$$
\mathrm{UTS}=1,405+0,008 \mathrm{SP}
$$


Berdasarkan hasil perhitungan $\mathrm{X}_{3}-\mathrm{Y}$ dapat diketahui hasil perhitungan nilai $\mathrm{t}$ hitung sebesar 1,675 sedangkan $\mathrm{t}$ tabel untuk $\alpha / 2=0,025$ dan derajat kebebasan 94 diperoleh 1,9. Dengan demikian $\mathrm{t}$ hitung $<\mathrm{t}$ tabel, yaitu $1,675<1,9$, berarti persepsi siswa mengenai kompetensi sosial guru tidak mempunyai pengaruh signifikan terhadap prestasi belajar siswa. Begitu pula apabila dilihat dari nilai sig., nilai sig. variabel persepsi siswa mengenai kompetensi sosial guru sebesar $0,097>0,05$, berarti variabel persepsi siswa mengenai kompetensi sosial guru tidak memiliki pengaruh signifikan terhadap prestasi belajar siswa. Dengan demikian, hipotesis yang menyatakan bahwa "Terdapat pengaruh positif dan signifikan persepsi siswa mengenai kompetensi sosial guru terhadap prestasi belajar siswa pada mata pelajaran sistem komputer di SMK Negeri 1 Banyudono" ditolak.

\section{Uji Hipotesis Keempat}

Dari hasil perhitungan regresi antara $\mathrm{X}_{3^{-}}$ $Y$ dapat diperoleh persamaan regresi sebagai berikut :

$$
\mathrm{UTS}=1,405+0,018 \mathrm{SP}
$$

Berdasarkan hasil perhitungan $\mathrm{X}_{4}-\mathrm{Y}$ dapat diketahui hasil perhitungan nilai $\mathrm{t}$ hitung sebesar 3,464 sedangkan $\mathrm{t}$ tabel untuk $\alpha / 2=0,025$ dan derajat kebebasan 94 diperoleh 1,9. Dengan demikian t hitung $>t$ tabel, yaitu 3,464>1,9, berarti persepsi siswa mengenai kompetensi profesional guru mempunyai pengaruh signifikan terhadap prestasi belajar siswa. Begitu pula apabila dilihat dari nilai sig., nilai sig. variabel persepsi siswa mengenai kompetensi kepribadian guru sebesar $0,001<0,05$, berarti variabel persepsi siswa mengenai kompetensi profesional guru memiliki pengaruh signifikan terhadap prestasi belajar siswa. Dengan demikian, hipotesis yang menyatakan bahwa "Terdapat pengaruh positif dan signifikan persepsi siswa mengenai kompetensi profesional guru terhadap prestasi belajar siswa pada mata pelajaran sistem komputer di SMK Negeri 1 Banyudono" diterima.

\section{Uji Hipotesis Kelima}

Hipotesis kelima yang akan diuji dalam penelitian ini adalah "Terdapat pengaruh positif dan signifikan persepsi siswa mengenai kompetensi pedagogik guru, persepsi siswa mengenai kompetensi kepribadian guru, persepsi siswa mengenai kompetensi profesional guru, persepsi siswa mengenai kompetensi sosial guru secara bersama - sama terhadap prestasi belajar siswa pada mata pelajaran sistem komputer di SMK Negeri 1 Banyudono". Persamaan Garis Regresi

$$
\begin{aligned}
& Y=a n+b_{1} \sum X_{1}+b_{2} \sum X_{2}+b_{3} \sum X_{3}+b_{4} \\
& \sum X_{4}
\end{aligned}
$$

$$
=1,405+0,006 X_{1}+0,006 X_{2}+0,018 X_{3}+0,008 X_{4}
$$

Koefisien korelasi (r), sebesar 0,702. Karena koefisien korelasi tersebut bernilai positif maka dapat dikatakan bahwa persepsi siswa mengenai kompetensi guru memiliki pengaruh yang positif terhadap prestasi belajar pada mata pelajaran sistem komputer siswa di SMK Negeri 1 Banyudono.

Nilai $\mathrm{R}$ Square $\left(\mathrm{R}^{2}\right)$ yang diperoleh sebesar 0,493, hal ini dapat diartikan bahwa 49,3 $\%$ perubahan prestasi belajar pada mata pelajaran sistem komputer siswa di SMK Negeri 1 Banyudono dipengaruhi oleh persepi siswa mengenai kompetensi guru, sedangkan sisanya sebesar 50,7\% dipengaruhi oleh variabel lain di luar penelitian.

Berdasarkan tabel 4.23 di atas diperoleh nilai $F_{\text {hitung }}$ sebesar 22,816 dan nilai $F_{\text {tabel }}$ dengan df $=94$ sebesar 2,47 dengan signifikansi sebesar 0,05 . Dengan demikian nilai $F_{\text {hitung }}>F_{\text {tabel }}(22,816$ $>2,70$ ), maka dapat disimpulkan persepi siswa mengenai kompetensi guru secara signifikan berpengaruh terhadap prestasi belajar pada mata pelajaran sistem komputer siswa di SMK Negeri 1 Banyudono. Sehingga hipotesis kelima yang diajukan dalam penelitian ini diterima.

\section{Sumbangan Relatif dan Sumbangan Efektif}

Hasil sumbangan relatif persepsi siswa mengenai kompetensi pedagogik guru terhadap minat mencari kerja sebesar $20,21 \%$, sumbangan relatif persepsi siswa mengenai kompetensi kepribadian guru terhadap prestasi belajar siswa sebesar $20,12 \%$, sumbangan relatif persepsi siswa mengenai kompetensi profesional guru terhadap prestasi belajar siswa sebesar $43,65 \%$, dan sumbangan relatif persepsi siswa mengenai kompetensi sosial guru terhadap prestasi belajar siswa sebesar $15,94 \%$, sedangkan sumbangan efektif persepsi siswa mengenai kompetensi pedagogik guru terhadap minat mencari kerja sebesar 9,96\%, sumbangan efektif persepsi siswa 
mengenai kompetensi kepribadian guru terhadap prestasi belajar siswa sebesar $9,92 \%$, sumbangan efektif persepsi siswa mengenai kompetensi profesional guru terhadap prestasi belajar siswa sebesar $21,52 \%$, dan sumbangan efektif persepsi siswa mengenai kompetensi sosial guru terhadap prestasi belajar siswa sebesar 7,86\%.

\section{Pembahasan}

Berdasarkan uji hipotesis maka dilakukan pembahasan hasil penelitian sebagai berikut :

Pengaruh Persepsi Siswa mengenai Kompetensi Pedagogik Guru terhadap Prestasi Belajar Siswa pada Mata Pelajaran Sistem Komputer

Hasil uji hipotesis pertama menunjukkan bahwa tidak terdapat pengaruh yang positif dan signifikan persepsi siswa mengenai kompetensi pedagogik guru terhadap prestasi belajar siswa pada mata pelajaran sistem komputer di SMK Negeri 1 Banyudono. Untuk pengujian signifikansi dengan uji $\mathrm{t}$ diperoleh hasil $\mathrm{t}_{\text {hitung }}<\mathrm{t}_{\text {tabel }}$ $(1,784<1,9)$ sehingga tidak terdapat pengaruh yang signifikan antara persepsi siswa mengenai kompetensi pedagogik guru terhadap prestasi belajar. Hasil ini berbeda dengan penelitian Umar (2014:38) yang menghasilkan kesimpulan bahwa persepsi siswa tentang kompetensi pedagogik guru berpengaruh positif dan signifikan terhadap prestasi belajar siswa. Hal yang perlu diketahui adalah variabel yang digunakan peneliti berbeda dengan variabel yang digunakan pada penelitian terdahulu tersebut, selain itu populasi yang digunakan oleh peneliti juga berbeda. Selain itu, dalam praktek guru sehari - hari, kompetensi pedagogik tidak bisa berjalan sendiri dikarenakan kompetensi ini juga harus berhubungan dan menyatu dengan kompetensi guru yang lain. Seorang guru yang memiliki kemampuan mengajar yang baik tanpa penguasaan yang baik dalam mata pelajaran yang diampunya akan menyebabkan kesalahan pemahaman oleh siswa sehingga berakibat pada prestasi siswa. Pernyataan tersebut didukung oleh Mulyasa (2007: 31) yang menyebutkan bahwa kompetensi guru diperlukan dalam rangka mengembangkan dan mendemonstrasikan perilaku pendidikan, bukan sekedar mempelajari keterampilan - keterampilan mengajar tertentu, tetapi merupakan penggabungan dan aplikasi suatu keterampilan dan pengetahuan yang saling bertautan dalam bentuk perilaku nyata. Mulyasa (2007: 32) mengungkapkan bahwa kompetensi guru lebih bersifat personal dan kompleks serta merupakan satu kesatuan utuh yang menggambarkan potensi yang mencakup pengetahuan, keterampilan, sikap dan nilai, yang dimiliki seseorang guru yang terkait dengan profesinya yang dapat direpresentasikan dalam amalan dan kinerja guru dalam mengelola pembelajaran di sekolah.

Pengaruh Persepsi Siswa mengenai Kompetensi Kepribadian Guru terhadap Prestasi Belajar Siswa pada Mata Pelajaran Sistem Komputer

Hasil uji hipotesis kedua menunjukkan bahwa tidak terdapat pengaruh yang positif dan signifikan persepsi siswa mengenai kompetensi kepribadian guru terhadap prestasi belajar siswa pada mata pelajaran sistem komputer di SMK Negeri 1 Banyudono. Untuk pengujian signifikansi dengan uji $t$ diperoleh hasil $t_{\text {hitung }}<t_{\text {tabel }}$ $(1,669<1,9)$ sehingga tidak terdapat pengaruh yang signifikan antara persepsi siswa mengenai kompetensi kepribadian guru terhadap prestasi belajar. Hasil ini berbeda dengan penelitian Rohmah dan Marimin (2015:37) dalam jurnalnya yang yang mengatakan bahwa berdasarkan hasil analisis regresi kompetensi kepribadian mempunyai pengaruh positif dan signifikan terhadap prestasi belajar. Hipotesis dalam penelitian ini ditolak dan didukung oleh pernyataan Mulyasa (2007: 32) yang mengungkapkan bahwa kompetensi guru lebih bersifat personal dan kompleks serta merupakan satu kesatuan utuh yang menggambarkan potensi yang mencakup pengetahuan, keterampilan, sikap dan nilai, yang dimiliki seseorang guru yang terkait dengan profesinya yang dapat direpresentasikan dalam amalan dan kinerja guru dalam mengelola pembelajaran di sekolah. Jadi, dapat dipahami bahwa kompetensi kepribadian ini tidak dapat berdiri sendiri untuk memberikan dampak positif dan signifikan terhadap prestasi belajar siswa.

Pengaruh Persepsi Siswa mengenai Kompetensi Sosial Guru terhadap Prestasi Belajar Siswa pada Mata Pelajaran Sistem Komputer

Hasil uji hipotesis ketiga menunjukkan bahwa tidak terdapat pengaruh yang positif dan 
signifikan persepsi siswa mengenai kompetensi sosial guru terhadap prestasi siswa belajar pada mata pelajaran sistem komputer di SMK Negeri 1 Banyudono. Untuk pengujian signifikansi dengan uji $\mathrm{t}$ diperoleh hasil $\mathrm{t}_{\text {hitung }}<\mathrm{t}_{\text {tabel }}$ $(1,675>1,9)$ sehingga terdapat pengaruh yang signifikan antara persepsi siswa mengenai kompetensi sosial guru terhadap prestasi belajar. Hasil ini berbeda dengan penelitian Rohmah dan Marimin (2015:38) dalam jurnalnya yang mengatakan bahwa berdasarkan hasil analisis regresi kompetensi sosial mempunyai pengaruh positif dan signifikan terhadap prestasi belajar. Hipotesis dalam penelitian ini ditolak dan didukung oleh pernyataan Mulyasa (2007: 32) yang mengungkapkan bahwa kompetensi guru lebih bersifat personal dan kompleks serta merupakan satu kesatuan utuh yang menggambarkan potensi yang mencakup pengetahuan, keterampilan, sikap dan nilai, yang dimiliki seseorang guru yang terkait dengan profesinya yang dapat direpresentasikan dalam amalan dan kinerja guru dalam mengelola pembelajaran di sekolah. Jadi, dapat dipahami bahwa kompetensi sosial ini tidak dapat berdiri sendiri untuk memberikan dampak positif dan signifikan terhadap prestasi belajar siswa.

Pengaruh Persepsi Siswa mengenai Kompetensi Profesional Guru terhadap Prestasi Belajar Siswa pada Mata Pelajaran Sistem Komputer

Hasil uji hipotesis keempat menunjukkan bahwa terdapat pengaruh yang positif dan signifikan persepsi siswa mengenai kompetensi profesional guru terhadap prestasi belajar siswa pada mata pelajaran sistem komputer di SMK Negeri 1 Banyudono. Konstanta sebesar 1,405 artinya jika persepsi siswa mengenai kompetensi profesional guru bernilai 0, maka prestasi belajar yang didapat oleh siswa adalah 1,405. Koefisien regresi variabel persepsi siswa mengenai kompetensi profesional guru sebesar 0,018 artinya jika persepsi siswa mengenai kompetensi profesional guru mengalami kenaikan sebesar 1 skor, maka prestasi belajar siswa akan mengalami kenaikan sebesar 0,018. Koefisien bernilai positif artinya terjadi hubungan yang positif (searah) antara persepsi siswa mengenai kompetensi profesional guru dengan prestasi belajar siswa. Persamaan menunjukkan bahwa nilai koefisien regresi bernilai positif yaitu 0,018. Sedangkan untuk pengujian signifikansi dengan uji t diperoleh hasil $t_{\text {hitung }}>t_{\text {tabel }}(3,464>1,9)$ sehingga terdapat pengaruh yang signifikan antara persepsi siswa mengenai kompetensi profesional guru terhadap prestasi belajar.

Dengan membandingkan perolehan sumbangan efektif nampak bahwa persepsi siswa mengenai kompetensi profesional guru memberikan pengaruh yang dominan terhadap prestasi belajar siswa dibandingkan persepsi siswa mengenai kompetensi pedagogik, kepribadian, dan sosial. Menurut penelitian yang dilakukan Yunita (2013) kompetensi profesional guru merupakan salah satu faktor penting yang harus diperhatikan dalam rangka meningkatkan hasil belajar siswa. Guru yang profesional akan mampu menciptakan suasana pembelajaran yang menyenangkan sehingga akan mendorong siswa untuk lebih aktif mengikuti proses pembelajaran. Persepsi siswa mengenai kompetensi profesional guru memiliki pengaruh yang positif dan signifikan memperkuat pernyataan Yustiyawan dan Nurhikmahyanti yang mengutip simpulan Alma (2010: 138) yang menyebutkan bahwa kompetensi profesional merupakan salah satu kemampuan dasar yang harus dimiliki seorang guru. Yustiyawan dan Nurhikmahyanti (2014: 121) menyimpulkan bahwa kompetensi profesional guru adalah kompetensi atau kemampuan yang berhubungan erat dengan penyesuaian tugas-tugas keguruan. Kompetensi ini merupakan kompetensi yang sangat penting karena langsung berhubungan dengan kinerja yang ditampilkan. Demikian kompetensi yang dimiliki oleh seorang guru mempunyai pengaruh terhadap keberhasilan kinerja guru dalam menjalankan tugas sebagai pendidik. Hasil penelitian ini diperkuat oleh Hamalik (Yunita, 2013) yang mengemukakan bahwa proses belajar dan hasil belajar para siswa bukan hanya ditentukan oleh sekolah, pola, struktur, dan isi kurikulum, akan tetapi sebagian besar ditentukan oleh kompetensi guru yang mengajar dan membimbing mereka.

Kompetensi profesional dalam penelitian ini merupakan satu - satunya kompetensi yang berpengaruh positif dan signifikan terhadap prestasi belajar siswa. Ruang lingkup kompetensi profesional yang merupakan penerapan dari kompetensi yang lain menjadi salah satu penyebabnya. Salah satu ruang lingkup kompetensi profesional yaitu "mengerti dan dapat menerapkan landasan kependidikan baik filosofi, psikologis, sosiologis dan sebagainya" dimaksudkan bahwa guru tidak hanya diwajibkan memiliki kompetensi pedagogik, kepribadian, profesional, dan sosial, melainkan harus mampu menerapkannya dalam kehidupan sehari - hari khususnya pada saat kegiatan belajar mengajar. 
Sebagian besar dari ruang lingkup kompetensi

profesional yaitu mengerti dan dapat menerapkan teori belajar sesuai taraf perkembangan peserta didik, mengerti dan dapat menerapkan metode pembelajaran yang bervariasi, mampu mengembangkan dan menggunakan berbagai alat, media, dan sumber belajar yang relevan, mampu mengorganisasikan dan melaksanakan program pembelajaran, dan mampu melaksanakan evaluasi hasil belajar peserta didik merupakan penerapan dari kompetensi pedagogik guru. Kemampuan guru untuk menumbuhkan kepribadian peserta didik
adalah penerapan dari kompetensi kepribadian guru.

Pengaruh Persepsi Siswa mengenai Kompetensi Pedagogik, Kompetensi Kepribadian, Kompetensi Sosial, Kompetensi Profesional Guru secara bersama - sama terhadap Prestasi Belajar

Siswa pada Mata Pelajaran Sistem
Komputer

Hasil hipotesis kelima menunjukkan terdapat pengaruh positif persepsi siswa mengenai kompetensi pedagogik, kompetensi kepribadian guru, kompetensi sosial, kompetensi profesional guru secara bersama - sama terhadap prestasi belajar siswa pada mata pelajaran sistem komputer di SMK Negeri 1 Banyudono. Berdasarkan hasil analisis regresi ganda diperoleh koefisien korelasi (r) antara $X_{1}, X_{2}, X_{3}$, dan $\mathrm{X}_{4}$ terhadap $Y$ sebesar 0,702 sehingga dapat dikatakan terdapat pengaruh yang positif persepsi siswa mengenai kompetensi pedagogik, kompetensi kepribadian guru, kompetensi sosial, kompetensi profesional guru secara bersama sama terhadap prestasi belajar siswa pada mata pelajaran sistem komputer. Sedangkan hasil uji F menggunakan $F_{\text {tabel }}$ dengan signifikansi 0,05, $d f=94$ sebesar 2,47, memperoleh nilai $F_{\text {hitung }}>F_{\text {tabel }}$ $(22,816>2,47)$.

Terbuktinya hipotesis kelima memberikan informasi bahwa persepsi siswa mengenai kompetensi guru baik kompetensi pedagogik, kompetensi kepribadian, kompetensi profesional dan kompetensi sosial memberikan pengaruh yang positif dan signifikan terhadap prestasi belajar siswa. Selain itu keempat kompetensi guru harus ada secara bersama - sama agar memberikan pengaruh yang signifikan terhadap prestasi belajar siswa seperti halnya yang telah diatur dalam Peraturan Menteri Pendidikan Nasional Nomor 16 Tahun 2007 tentang Standar Kualifikasi Akademik dan Kompetensi Guru bahwa kompetensi guru mencakup empat (4) aspek kompetensi, yaitu kompetensi pedagogik, kompetensi kepribadian, kompetensi profesional, dan kompetensi sosial. Selain itu, Borang dalam artikel seminar nasionalnya yang berjudul Upaya Peningkatkan Kompetensi dan Profesionalisme Guru SMK di Era Sertifikasi menyebutkan bahwa keempat bidang kompetensi yaitu kompetensi pedagogik, kompetensi kepribadian, kompetensi profesional, dan kompetensi sosial tidak berdiri sendiri-sendiri, melainkan saling berhubungan dan saling mempengaruhi satu sama lain.

Keempat kompetensi guru ini saling terikat satu sama lain terutama pada kompetensi profesional guru. Dalam kompetensi profesional guru tersebut terdapat ruang lingkup yang menaungi kompetensi guru yang lain. Selain itu, beberapa kompetensi memiliki indikator kompetensi yang berhubungan satu sama lain. Misalnya indikator kompetensi pedagogik yaitu pemahaman terhadap peserta didik berhubungan dengan indikator kompetensi sosial yaitu bergaul secara efektif dengan peserta didik, sesama pendidik, tenaga kependidikan, orang tua/wali peserta didik. Dengan adanya pemahaman terhadap peserta didik maka diharapkan guru akan mampu bergaul secara efektif dengan peserta didik.

Mengembangkan kurikulum yang terkait dengan mata pelajaran yang diampu merupakan indikator dari kompetensi pedagogik. Indikator ini dapat tercapai jika guru menguasai standar kompetensi dan kompetensi dasar mata pelajaran yang diampu yang merupakan salah satu indikator dalam kompetensi profesional. Beberapa contoh hubungan antar indikator tersebut merupakan penggambaran dari keempat kompetensi yang bersama - sama akan memberikan pengaruh yang positif dan signifikan terhadap prestasi belajar siswa.

\section{SIMPULAN DAN SARAN}

\section{Simpulan}

Persepsi siswa mengenai kompetensi pedagogik guru tidak berpengaruh positif dan signifikan terhadap prestasi belajar siswa pada mata pelajaran sistem komputer di SMK Negeri 1 Banyudono. (2) Persepsi siswa mengenai kompetensi kepribadian guru tidak berpengaruh positif dan signifikan terhadap prestasi belajar siswa pada mata pelajaran sistem komputer di SMK Negeri 1 Banyudono. (3) Persepsi siswa mengenai kompetensi sosial guru tidak berpengaruh positif dan signifikan terhadap 
prestasi belajar siswa pada mata pelajaran sistem komputer di SMK Negeri 1 Banyudono. (4)

Persepsi siswa mengenai kompetensi profesional guru berpengaruh positif dan signifikan terhadap prestasi belajar siswa pada mata pelajaran sistem komputer di SMK Negeri 1 Banyudono. (5) Persepsi siswa mengenai kompetensi pedagogik, kompetensi kepribadian, kompetensi sosial, kompetensi profesional guru secara bersama - sama berpengaruh positif dan signifikan terhadap prestasi belajar siswa pada mata pelajaran sistem komputer SMK Negeri 1 Banyudono.

\section{Saran}

\section{Bagi Guru}

Guru mata pelajaran sistem komputer hendaknya menjaga persepsi baik siswa karena dari penelitian ini dapat diambil kesimpulan bahwa persepsi siswa mengenai kompetensi guru berpengaruh terhadap prestasi belajar siswa. (2) Kompetensi yang dimiliki guru hendaknya mencakup keempat aspek kompetensi yaitu kompetensi pedagogik, kompetensi kepribadian, kompetensi profesional, dan juga kompetensi sosial sehingga kompetensi tersebut memiliki pengaruh yang signifikan terhadap prestasi belajar siswa. (3) Dalam upaya meningkatkan persepsi siswa mengenai kompetensi guru hendaknya guru sering berinteraksi dengan siswa, misalnya dengan menanyakan masalah belajar siswa agar guru mengetahui keadaan siswa pada saat pembelajaran.

\section{Bagi Sekolah}

Pihak sekolah hendaknya ikut melakukan monitoring dan evaluasi secara bertahap terhadap guru terkait kompetensi mengajar agar kompetensi guru semakin meningkat.

\section{DAFTAR PUSTAKA}

$\begin{array}{cr}\text { Mulyasa. (2007). } & \text { Standar } \\ \text { Kompetensi } & \text { dan } \\ \text { Sertifikasi } & \text { Guru. } \\ \text { Bandung: } & \text { Remaja } \\ \text { Rosdakarya. } & \end{array}$

Mulyasa. (2013). Uji Kompetensi dan Penilaian Kerja Guru. Bandung: Remaja Rosdakarya.
Pangestuti, F. (2012). Persepsi Siswa mengenai Kompetensi Guru terhadap Prestasi

Belajar Akuntansi Siswa Kelas XI Program Keahlian Akuntansi di SMK YPPM Boja Tahun Ajaran 2010/2011. Skripsi Tidak Dipublikasikan. Semarang: Universitas Negeri Semarang

Peraturan Menteri Pendidikan Nasional Republik Indonesia Nomor 16 Tahun 2007 tentang Standar Kualifikasi Akademik dan Kompetensi Guru.

Phillips, L. T., Weisbuch, M., Ambady, M. (2014). People perception: Social vision of groups and consequences for organizing and interacting. Research in Organizational Behavior, 34 (2014), 101127. Diperoleh pada

12 Juli 2016, dari www.elsevier.com/locate/riob

Rohmah, K, Marimin. (2015). Pengaruh Persepsi Siswa mengenai Keterampilan Mengajar, Kompetensi Kepribadian, dan Kompetensi Sosial Guru, terhadap Prestasi Belajar Siswa Program Studi Administrasi Perkantoran di SMK Negeri 1 Purwodadi. Jurnal Pendidikan Ekonomi Dinamika Pendidikan, 10(1), 28 - 41. Diperoleh pada

tanggal 15 Juni 2016 dari http://lib.unnes.ac.id/21343/1/710141 1228-s.pdf

Ratminingsih, N. M. (2015). Profil Profesionalisme Dosen Jurusan Pendidikan Bahasa Inggris. Singaraja: Universitas Pendidikan Ganesha.

Sugiyono. (2015). Metode Penelitian Pendidikan. Bandung: Alfabeta.

Undang-Undang Nomor 20 Tahun 2003 tentang Sistem Pendidikan Nasional.

Undang-Undang Republik Indonesia Nomor 14 Tahun 2005 tentang Guru dan Dosen.

Yunita, R. (2013). Pengaruh Persepsi Siswa mengenai Kompetensi Profesional Guru Akuntansi dan Fasilitas Belajar terhadap Hasil Belajar Akuntansi Siswa Kelas XI IPS SMA N 1 Bergas Kab. Semarang Tahun Ajaran 2012/2013.Skripsi Tidak Dipublikasikan. Semarang: Universitas Negeri Semarang 